\title{
APRESENTAÇÃO do Dossiê INCÊNDIOS: INFÂNCIAS Do PRESENTE
}

Julio Groppa Aquino ${ }^{1}$

Fabiana A. A. Jardim²

Universidade de São Paulo, Brasil

É com alegria que introduzimos ao leitor o dossiê Incêndios: infâncias do presente, o qual reúne um conjunto de nove artigos dedicados à peça de teatro de Wadji Mouawad, Incêndios, e ao filme homônimo a que ela deu origem. Tratou-se de colocar ambas as obras em perspectiva, no que diz respeito às suas relações possíveis com as temáticas da educação, da infância e da filosofia.

A motivação para a realização do dossiê surgiu a partir do reconhecimento de que Incêndios consiste em um acontecimento ético, estético, político e filosófico de monta, ao trazer para a cena do pensamento um conjunto de temas/problemas que atravessam nossa experiência do presente.

O ator, diretor e dramaturgo Wadji Mouawad nasceu em 1968, em uma comunidade cristã maronita no Líbano. Devido à guerra civil que ali se estendeu de 1975 a 1990, sua família exilou-se na França em meados dos anos 1970, onde viveram até o governo francês não mais lhes conceder o direito de moradia. Da França partiram então, na década seguinte, para viver em Montreal, onde ele se formou na Escola Nacional de Teatro do Canadá.

As experiências da guerra e do exílio, bem como seus efeitos de subjetivação, são questões que permeiam sua obra, aparecendo a cada vez de modo distinto: em Litoral, a primeira peça da quadrilogia intitulada O Sangue das promessas da qual faz parte Incêndios, um filho busca um lugar para enterrar o pai que mal chegou a conhecer; em Incêndios, trata-se de um trabalho de recepção da herança da mãe, por parte dos filhos, um casal de gêmeos; em Florestas, uma mulher parte em busca das histórias das mulheres que lhe antecederam, enfrentando os laços de sangue e ódio; em Céus, trata-se de pôr em questão a centralidade da memória.

\footnotetext{
${ }^{1}$ E-mail: groppaq@usp.br

2 E-mail: fajardim@usp.br
} 
O sentido trágico presente em suas peças, e especialmente em Incêndios, não deve ser subestimado: em 2015, durante um período de residência artística, Mouawad iniciou um projeto para encenar, ao ar livre e em sequência, sete peças de Sófocles. No mesmo ano de 2015, o diretor libanês-canadense esteve no Brasil em uma curta temporada da peça Solos, concebida e interpretada por ele próprio.

Incêndios, de 2003, é, sem dúvida, seu trabalho mais conhecido, traduzido para muitas línguas e encenado em diferentes países. Além disso, a peça deu origem a uma belíssima adaptação cinematográfica homônima, em 2010, dirigida por Denis Villeneuve. O filme foi bastante premiado, tendo sido indicado ao Oscar de melhor filme estrangeiro. E é bastante interessante observar como peça e filme se distinguem em vários aspectos, a despeito de narrarem uma história comum. Isso porque Villeneuve não pretendeu transpor a linguagem do teatro ao cinema; ao contrário, traduziu a narrativa de Mouawad em linguagem visual, dialogando, inclusive, com toda a saturação das imagens de guerras no Oriente Médio.

Quanto à iniciativa deste dossiê, foi proposto aos autores dos artigos que refletissem sobre a experiência do contato com Incêndios, tanto em sua versão para o teatro quando a do filme. A enorme potência do universo criado por Mouawad revela-se nos diferentes enquadramentos analíticos que foram operados pelos autores. Conforme se verá, Incêndios nos toca de diversos modos, articulando-se a experiências pessoais ou intelectuais e produzindo no leitor/espectador uma impressão profunda, que não é apenas de assombro, mas que também conduz ao silêncio e aos trabalhos da memória. A montagem da peça no México fazia menção aos 43 estudantes normalistas desaparecidos; no Brasil, a atriz Marieta Severo dedicou a montagem a Zuzu Angel, relacionando assim o tema da peça à difícil herança da ditadura civil-militar no país. São apenas dois exemplos para evidenciar o quanto a obra tem de atualidade num contexto em que as guerras, real ou metaforicamente, impõem-se como um legado longe de se encerrar: das trincheiras do Oriente Médio, passando pelos conflitos na África, até as ruas das metrópoles sul-americanas. 
Refletir sobre a experiência do presente a partir de Incêndios, no que se refere à infância, à educação e à filosofia, foi a tarefa que os autores deste dossiê se dispuseram, corajosa e generosamente, a levar a cabo. Por essa razão, a eles agradecemos. Também agradecemos de modo especial aos editores da revista, os quais acolheram de pronto o projeto do dossiê. Esperamos, por fim, que os leitores também possam encontrar nos textos aqui reunidos ocasião de reflexão crítica sobre nossa experiência contemporânea - doravante levemente iluminada pelas chamas desses diversos incêndios que compõem o exercício coletivo de pensamento aqui ensejado. 